\title{
A EDUCAÇÃO INFANTIL NA PANDEMIA: a experiência de uma escola pública antirracista
}

\author{
Raul Cabral França \\ Universidade Estadual de Campinas - Unicamp \\ Marina Basques Masella \\ Escola Municipal de Educação Infantil Nelson Mandela - São Paulo \\ Ana Maria Falcão de Aragão \\ Universidade Estadual de Campinas - Unicamp
}

\begin{abstract}
Resumo
Este artigo é parte de uma pesquisa sobre o projeto político-pedagógico de uma escola municipal de educação infantil que adota as relações étnico-raciais como um de seus eixos principais. Apresenta um estudo de caso sobre o trabalho desenvolvido remotamente pela unidade escolar durante a suspensão do atendimento presencial, em razão da pandemia de COVID-19. Analisa as possibilidades e os limites para efetivar, nesse contexto, um currículo antirracista, centrado na ludicidade e na afetividade; discute, também, os desafios para a inclusão de todas as crianças no processo e para a garantia do direito à educação. As fontes do estudo foram as propostas documentadas nas redes sociais, entrevistas e um mapeamento realizado pela escola. A análise é realizada ao longo de uma narrativa, identificando quatro fases no desenvolvimento do trabalho remoto: a manutenção do vínculo com as crianças, a reorganização das propostas, a construção de um projeto didático e, por fim, a temporária consolidação. Ao narrar e discutir esse processo marcado por reflexões críticas, aprendizados e mudanças, o artigo pretende contribuir para o debate sobre concepções e práticas na educação infantil, das quais o trabalho remoto emergencial é apenas um reflexo.
\end{abstract}

Palavras-chave: Educação Infantil, Educação Antirracista, Isolamento Social, Ensino Remoto

\begin{abstract}
This article is part of a research on the political-pedagogical project of a municipal school for early childhood education that adopts ethnic-racial relations as one of its main pillars. It presents a case study about the work developed remotely by the school unit during the closure forced by the COVID-19 pandemic. It analyzes the possibilities and limits to implement, in this context, an antiracist curriculum, focused on ludicity and affectivity; it also discusses the challenges to include all children in the process and to guarantee the right to education. The sources of the study were the initiatives documented in the social networks, interviews and a survey carried out by the school. The analysis is made along a narrative, identifying four phases in the development of the remote work: the maintenance of the bond with the children, the reorganization of the initiatives, the elaboration of a didactic project and, finally, the temporary consolidation. By reporting and discussing this process marked by critical reflections, learning and changes, the article intends to contribute to the debate on conceptions and practices in early childhood education, of which remote emergency work is only a reflex.
\end{abstract}

Keywords: Early Childhood Education, Racial Bias, School Closing, Distance Education

ISSN 1645-1384 (online) www.curriculosemfronteiras.org 


\section{Introdução}

A pandemia de COVID-19 colocou educadoras e educadores diante de dilemas inéditos. Se o currículo da escola não pode ser reduzido ao ensino de um conjunto de conhecimentos - posto que também é feito de relação, diálogo, afetividade e experiência -, a convivência no ambiente escolar é insubstituível. Porém, diante da necessidade de isolamento social para a proteção da saúde pública, também se tornou temporariamente impossível a convivência presencial nas unidades escolares.

A crise nos convidou a graves reflexões. Reconhecendo, por um lado, a grande contribuição da tecnologia para possibilitar o trabalho remoto das escolas durante a pandemia, é preocupante observar a armadilha de que as experiências recentes sirvam de balão de ensaio para delinear um futuro de digitalização permanente, o que desfiguraria o próprio fenômeno educativo (MORGADO; SOUSA; PACHECO, 2020). E embora seja uma situação imprevista e emergencial, não se pode desconsiderar a desigualdade abissal entre as classes sociais quanto às condições de acesso às tecnologias de comunicação, nem usar o pretexto da excepcionalidade para considerar aceitável que uma parte das crianças seja excluída do direito à educação (FERREIRA; BARBOSA, 2020).

Estávamos, como tantos, em meio a uma pesquisa quando a pandemia começou; documentando o trabalho de uma escola municipal de educação infantil em São Paulo que transformou a luta contra o racismo em um dos eixos principais de seu projeto políticopedagógico (PPP). O trabalho da Escola Municipal de Educação Infantil (EMEI) Nelson Mandela tem sido amplamente reconhecido e, com isso, transformado a escola em uma importante promotora da pauta da educação antirracista: nos primeiros meses de 2020, seu projeto já foi matéria na revista Nova Escola ${ }^{1}$, no jornal O Estado de S. Paulo ${ }^{2}$ e na BBC News $^{3}$; foi objeto de três publicações acadêmicas (GONÇALVES; DUARTE, 2020; MASELLA; DUARTE, 2020; NASCIMENTO, 2020); foi apresentado em lives da Faculdade de Educação da Universidade de São Paulo ${ }^{4}$ e em um encontro virtual de famílias dos colégios particulares Vera Cruz e Oswald de Andrade (São Paulo) ${ }^{5}$; chegou, pela terceira vez consecutiva, à final do Prêmio Paulo Freire de Qualidade do Ensino Municipal ${ }^{6}$.

Concordamos com Apple (2011, p. 23) que "entre as tarefas dos educadores críticos estão a de participar de movimentos que buscam criar instituições mais criticamente democráticas na educação e na sociedade como um todo, bem como agir como secretários desses movimentos e instituições para que esses sucessos se tornem visíveis"7. Documentar, analisar e compartilhar práticas emancipatórias inventadas na escola pública, no cotidiano concreto de professoras e professores, é uma forma extremamente potente de colaborar com as mudanças que desejamos. Este artigo, fruto de uma parceria entre escola e universidade, é co-escrito por pessoas de ambas as instituições. Acreditamos que, produzindo conhecimento na/com a escola - e não apenas sobre a escola -, a complementaridade dos pontos de vista permite a construção de saberes mais representativos.

Este $\operatorname{artigo~}^{8}$ discute os caminhos que a equipe de educadoras ${ }^{9}$ está percorrendo para manter vivos os princípios do projeto antirracista da escola neste momento absolutamente atípico, em que as atividades presenciais estão impossibilitadas pela pandemia de COVID- 
19. E para além da discussão sobre alternativas no campo da prática pedagógica, este estudo de caso também enseja refletir sobre opções políticas e epistemológicas em tempos de exceção. Não se fala, aqui, em Educação Infantil à distância. Fala-se em ensino remoto emergencial, em um contexto em que as mídias digitais se tornam inevitáveis como meio de comunicação entre as escolas e os alunos (BEHAR, 2020; HODGES et al., 2020); nas condições dadas, trata-se de resistir e buscar garantir o direito à educação por todos os meios possíveis, e por isso as alternativas de educação remota não podem ser menosprezadas.

A crise se instalou sem que houvesse conhecimentos e métodos previamente construídos, discutidos e socialmente validados sobre práticas remotas na educação infantil. A necessidade fez com que as respostas possíveis começassem a ser construídas nas/pelas escolas neste momento, e um dos papéis da pesquisa, segundo acreditamos, é auxiliar na discussão e sistematização de tais propostas. Os métodos usados para compor esta análise serão expostos a seguir. Adiante, apresentamos brevemente o histórico do projeto e as principais características do trabalho pedagógico da EMEI Nelson Mandela, consolidadas ao longo dos anos, para avaliar quais desses aspectos estão sendo possíveis de contemplar por meio de atividades remotas e quais são as lacunas que, apesar dos melhores esforços, permanecem abertas. As análises são feitas com base no conjunto de atividades realizado virtualmente durante a pandemia. Por fim, reunimos algumas considerações finais, ensaiando respostas aos dilemas apresentados no início.

\section{Método}

Assim como a pesquisa da qual faz parte, este artigo é um estudo de caso (YIN, 2013) sobre o trabalho pedagógico de uma escola pública de educação infantil. As categorias utilizadas na análise foram construídas a partir da codificação (SALDAÑA, 2016) do PPP da escola, que é anualmente revisitado pelas educadoras e foi atualizado no final de 2019. Por apresentar em detalhes as concepções pedagógicas e práticas da unidade escolar, consideramos o documento adequado para ser tomado como base para mapear as principais características da proposta educacional da EMEI Nelson Mandela.

O processo de codificação para formação das categorias foi feito com o suporte de um software, ATLAS.ti 8. Embora a metodologia não dependa, a priori, de nenhuma ferramenta específica, os softwares de apoio à análise de dados qualitativos favorecem sobremaneira essa tarefa. É importante ressaltar que a ferramenta não substitui os pesquisadores na tomada de decisões sobre a metodologia, nem automatiza o processo de análise e interpretação. $\mathrm{O}$ que os programas fazem é reduzir o trabalho manual dos pesquisadores para organizar e codificar um alto volume de dados (LAGE, 2011).

Em razão de sua própria natureza virtual, o trabalho pedagógico realizado pela escola durante a pandemia está inteiramente documentado na internet. Todas as propostas foram publicadas na página da escola nas redes sociais Facebook $^{10}$ e Instagram $^{11}$, por onde as crianças fazem o acesso por intermédio dos seus familiares e responsáveis. Além disso, para este artigo foram conduzidas entrevistas semiestruturadas com a diretora e com uma 
professora da unidade ${ }^{12}$. O processo de desenvolvimento do trabalho pedagógico é descrito em forma narrativa, com base nos dados citados; serão feitas referências às fontes informantes apenas nos casos em que essa informação for relevante para contextualizar a análise. As categorias construídas a partir do PPP serão o instrumento para analisar a narrativa do processo e discutir as possibilidades e limites do ensino remoto na efetivação do currículo antirracista, principal característica do projeto pedagógico da escola.

\section{EMEI Nelson Mandela: uma breve história do projeto antirracista}

A história desse projeto pedagógico centrado nas relações étnico-raciais começa em 2011. Naquele ano, a EMEI Guia Lopes, de São Paulo - SP, elaborou uma proposta fundamentada nas leis 10.639/03 e 11.645/08 - normas que acrescentaram à Lei de Diretrizes e Bases (LDB) a obrigatoriedade do estudo da história e da cultura africana, afrobrasileira e indígena. Pretendia-se, assim, tornar visível a história de vida das crianças e de suas famílias, valorizando os aspectos identitários da comunidade a que pertenciam. A introdução da temática no cotidiano da unidade escolar ocorreu por meio de uma prática que já era adotada ali há tempos: as narrativas lúdicas, que perpassam todos os projetos da escola, convidando às crianças ao encantamento, à fantasia e à afetividade, e deste modo apresentando questões do cotidiano a serem problematizadas e discutidas. Os personagens principais de tais narrativas são as figuras de afeto, bonecos de pano em tamanho grande cujas histórias, construídas em conjunto com as crianças ao longo dos projetos, tornam-se uma tradição a ser passada "de geração em geração", dos alunos antigos aos recém-chegados.

$\mathrm{O}$ anúncio da chegada de um novo personagem instigou as crianças: Azizi Abayomi, príncipe da África do Sul. A vinda do ilustre convidado despertou a curiosidade e disparou uma série de questionamentos. As educadoras aproveitaram, então, para explorar as hipóteses das crianças: o que elas já conheciam sobre nações da África? O que era preciso para ser um rei ou uma rainha? Como haveria de ser o príncipe Azizi Abayomi? Os estereótipos construídos pela literatura infantil e pelos desenhos animados ficaram evidentes nas produções das crianças. Os príncipes desenhados e os elementos associados remetiam, quase sempre, ao referencial europeu.

Quando Azizi enfim chegou, com direito a festa de recepção, as crianças tiveram uma surpresa. Ou um choque. Aquele não se parecia com o príncipe imaginado. Os estereótipos estavam sendo desconstruídos pela chegada de um príncipe africano (FRANÇA; MASELLA, 2019, n.p.).

A escola, que considera todos os seus espaços, a todo tempo, como territórios de aprendizagem, passou a refletir as marcas do projeto:

A partir de então, os bonecos brancos que ocupavam o centro da narrativa deram lugar a Azizi. As atividades na cozinha experimental tiveram como inspiração a culinária afro-brasileira; a sala de leitura ficou repleta de lendas africanas; as 
pesquisas e jogos envolveram as diferenças culturais; na ludoteca, jogos africanos; no espaço de artes, a produção de máscaras, mandalas e estampas para tecidos. As crianças queriam saber de onde Azizi tinha vindo, como tinha nascido negro, como era sua família, seus costumes, brincadeiras e músicas prediletas. A festa junina daquele ano foi transformada em uma festa afro-brasileira, que também foi uma apresentação de todo o trabalho e os conhecimentos produzidos pelas crianças. As famílias foram envolvidas de uma forma até então inédita, acompanhando de perto o projeto e as descobertas de seus filhos e filhas (FRANÇA; MASELLA, 2019, n.p.).

Para além da fantasia e da ludicidade, as histórias com as figuras de afeto criam espaços privilegiados para conversar sobre conflitos cotidianos, refletir sobre relações e problematizar preconceitos. E não apenas dentro da escola, mas também envolvendo as famílias. Um dos exemplos foi quando algumas crianças sugeriram que Azizi deveria se casar com Sofia - uma figura de afeto branca que fazia parte das narrativas -, e houve estranhamento por parte de outras. Questionadas pelas educadoras sobre o porquê, parte das crianças apontava as diferenças entre ambos os personagens como motivo para que não se casassem. $\mathrm{O}$ projeto se desenvolveu a partir de uma escuta atenta às respostas e indagações das crianças, e nessa trajetória também pediu às famílias para compartilhar com os filhos suas histórias e fotografias. Muitas crianças ouviram, assim, como os próprios pais se conheceram e começaram a namorar antes de elas nascerem. Foram reconhecendo, em sua própria família, a história de encontros e a formação de laços entre pessoas diferentes.

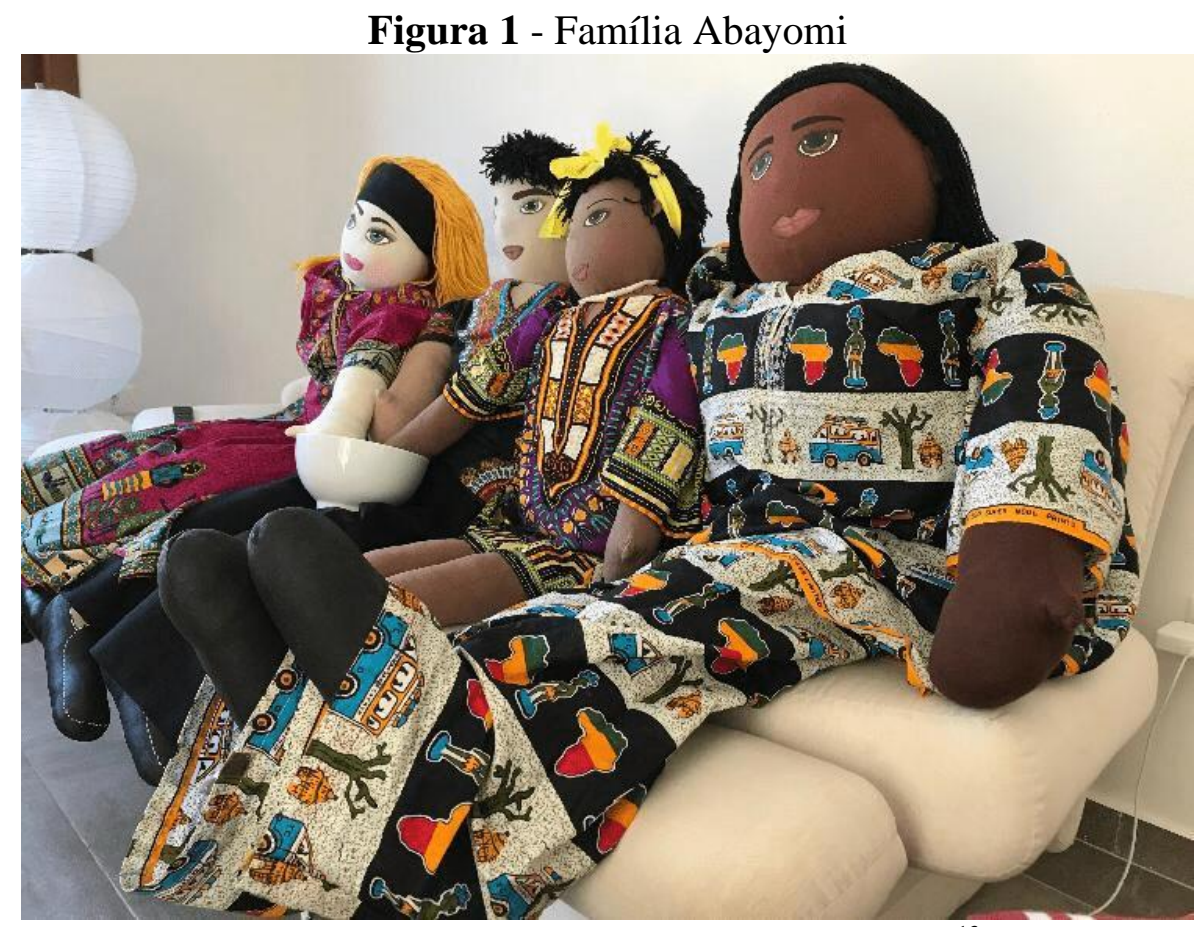

Fonte: Facebook, página da EMEI Nelson Mandela ${ }^{13}$ 
O trabalho sobre as relações étnico-raciais não foi construído sem tensões. Ainda no primeiro ano, em 16 de outubro de 2011, um ataque veio na forma de pichação no muro da escola, com a mensagem: "vamos cuidar do futuro de nossas crianças brancas", acompanhada da suástica nazista. A notícia teve repercussão nacional, trazendo a educação antirracista para o centro do debate. $\mathrm{O}$ projeto da escola ganhou visibilidade e demonstrou sua importância, uma vez que a agressão recebida era um sintoma do racismo profundamente enraizado na sociedade brasileira.

Figura 2 - Pichação racista no muro da EMEI Guia Lopes

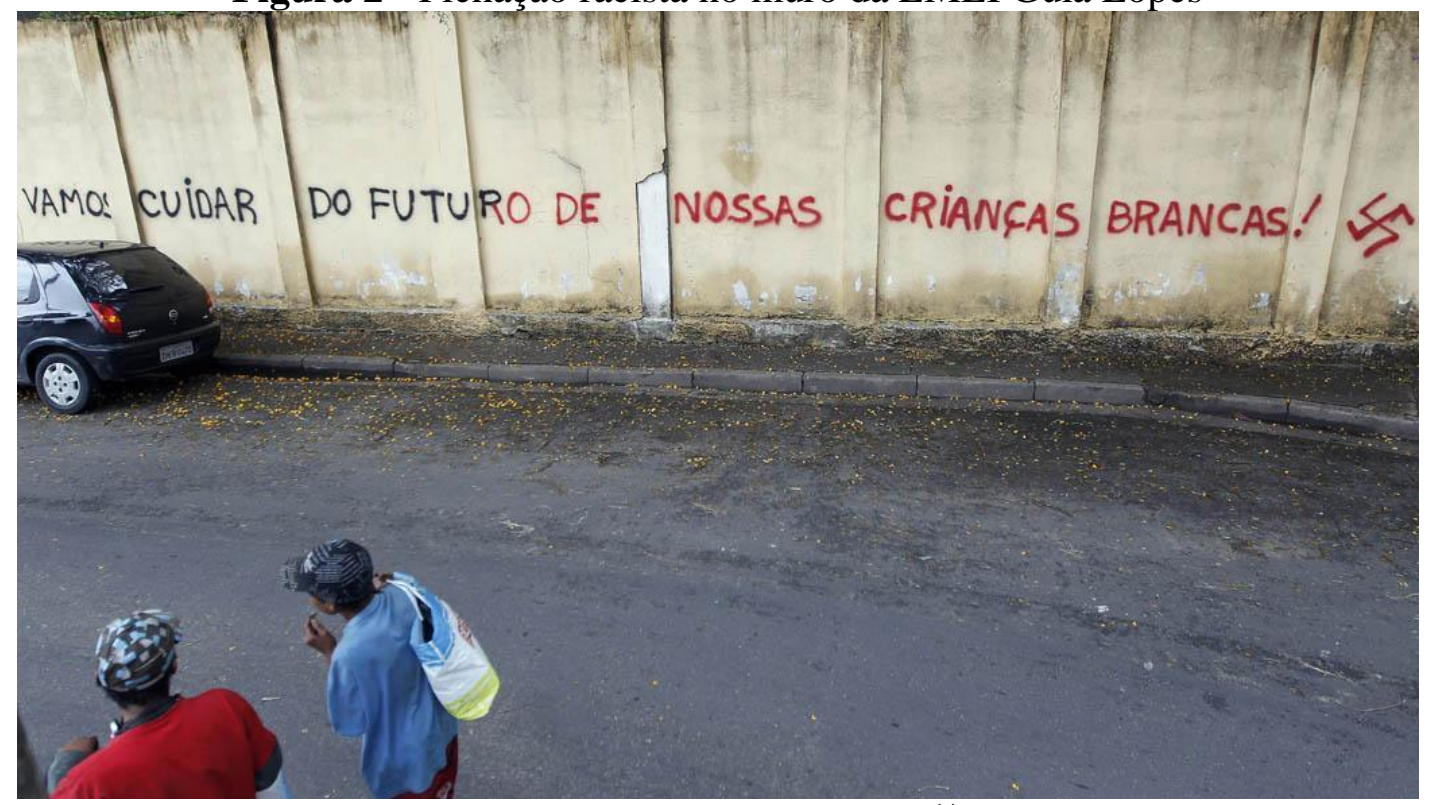

Fonte: Epitácio Pessoa/AE/Veja ${ }^{14}$

A resposta da EMEI Guia Lopes foi assertiva: convidou as crianças e a comunidade para conversar sobre o ocorrido e iniciar um projeto para cobrir o muro com arte, cores e mensagens que afirmassem a paz, o respeito e a diversidade. O projeto continuou pelos anos seguintes, e em 2014 teve como eixo principal a história da vida de Nelson Mandela, líder sul-africano que falecera no ano anterior. As narrativas e propostas didáticas tiveram como temática a luta contra a segregação racial e pela igualdade de direitos. $\mathrm{Na}$ fantasia das crianças, Mandela se tornou o Vovô Madiba, avô do príncipe Azizi Abayomi e uma figura muito querida entre elas.

No ano de 2015, diante da necessidade de reformar quase que totalmente o muro que trazia as marcas da história do projeto, o Conselho de Escola e a Associação de Pais e Mestres fizeram uma sugestão para selar de forma definitiva o compromisso da escola com a luta antirracista: alterar o nome da unidade, escolhendo um que simbolizasse com toda a potência a proposta desenvolvida ali. Uma campanha se iniciou, milhares de assinaturas foram coletadas e, em 2016, a escola passou a se chamar EMEI Nelson Mandela. 
A pichação de 2011 não foi a única. Em março de 2012, um dos portões amanheceu com a frase "Preserve a raça branca". Em outubro de 2018, período em que se acentuou a polarização política e ideológica no país, outro portão foi pichado com a mensagem "A escola não educa seus filhos". Desta vez, porém, em vez de cobrir a pichação, a EMEI Nelson Mandela respondeu ao ataque de forma diferente: chamou a atenção das crianças e da comunidade para a frase que havia sido pichada e organizou uma agenda de ações para refletir sobre a questão: o que é educar? As ideias foram debatidas e registradas, as reflexões foram incorporadas ao PPP da escola e o muro da frente se tornou um grande mural com a figura de Nelson Mandela, o título "Educar é" e as frases das crianças e da comunidade.

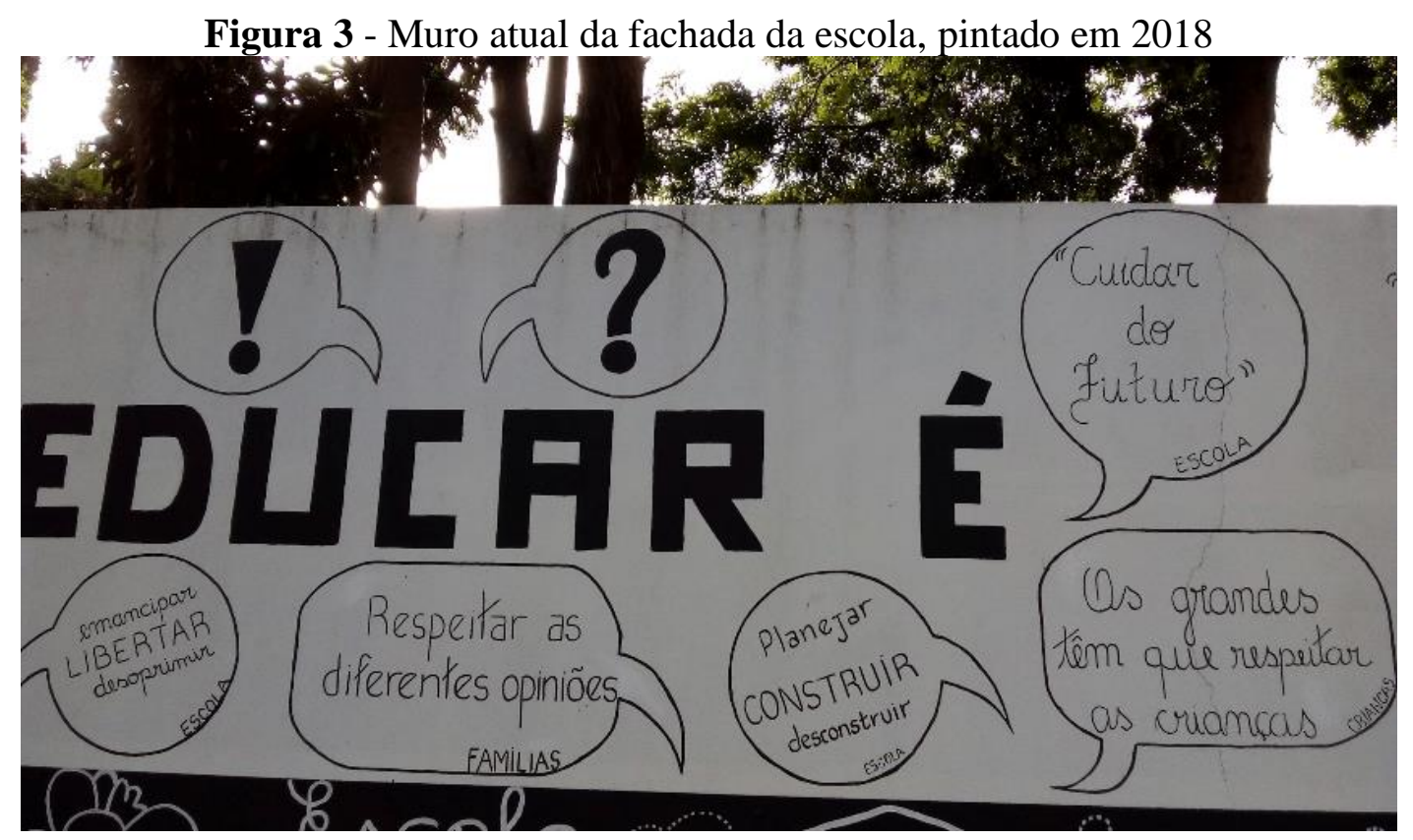

Fonte: Arquivo pessoal

Ao longo dos anos, a EMEI Nelson Mandela sistematizou e institucionalizou, em seu PPP, os principais projetos e práticas realizadas na escola. A equipe possui uma relação íntima e dinâmica com o documento; no início de cada ano, cada educadora recebe uma cópia do PPP e é convidada a estudá-lo por meio de diversas propostas de leitura, reflexão e debate, nos horários coletivos e de reuniões pedagógicas. Esta prática tem o objetivo de que a história da escola continue sendo escrita com novos capítulos, sempre com base nas memórias já construídas. Esses momentos de estudo são importantes para que as educadoras novas na unidade se familiarizem, aos poucos, com a história da escola e suas práticas pedagógicas já consolidadas. Ao longo do ano, a partir das vivências e projetos vividos, o documento é revisado e atualizado para o ano seguinte. Deste modo, o PPP tornou-se um documento vivo e significativo para o cotidiano da escola, escrito de maneira coletiva por todos os sujeitos que dela fazem parte. 
A EMEI Nelson Mandela está localizada no bairro do Limão, zona norte de São Paulo. Pertence, desde 2018, ao programa "Escola de Tempo Integral” do município. Atende 212 crianças, em 7 turmas multietárias (de 4 a 6 anos), das 08h às 16h. Cada turma conta com duas professoras - uma atuando das $08 \mathrm{~h}$ às $12 \mathrm{~h}$ e outra das $12 \mathrm{~h}$ às $16 \mathrm{~h}$. A seguir, a descrição das nove categorias que se relacionam ao aspecto antirracista de seu projeto pedagógico:

Compromisso da unidade escolar com valores ético-políticos - A proposta pedagógica da EMEI Nelson Mandela faz opções éticas, políticas e epistemológicas. Sua concepção de educação se baseia nos preceitos da democracia e no desejo de uma sociedade mais justa, solidária e menos desigual. Seu currículo é construído para formar sujeitos mais tolerantes, que respeitem a diversidade, sejam capazes de conhecer a si mesmos e de viver em paz com seus pares e com a natureza. Uma das principais expressões desse compromisso é a presença permanente de dois temas transversais em todas as suas propostas: as relações étnico-raciais e de gênero e as relações sustentáveis no planeta.

Luta contra o racismo e a discriminação - Efetiva-se por meio do primeiro tema transversal permanente do currículo: as relações étnico-raciais e de gênero. É pauta constante da formação continuada das educadoras e está presente em todos os projetos didáticos da unidade escolar. O projeto do ano de 2018, por exemplo, celebrou o centenário do patrono da escola, Nelson Mandela, por meio do estudo da sua história de vida e de valores que inspiram as sociedades africanas e afro-brasileiras: coletividade, comunitarismo, ancestralidade, oralidade e memória, entre outros. Em 2019, cada turma da escola recebeu o nome de uma madrinha, musa e mulher negra brasileira cuja vida e legado tanto contribuíram para a arte e cultura de nosso país: Ivone Lara, Clementina de Jesus, Leci Brandão, Dandara dos Palmares, Lia de Itamaracá, Sandra de Sá e Elza Soares. As histórias dessas personalidades também foram estudadas pelas crianças como inspiração para que pudessem conhecer sobre suas autobiografias. A escolha pelas mulheres brasileiras protagonizando o projeto didático de 2019 se deu após uma criança observar que Nelson Mandela teve como referência a presença de muitas mulheres, parte de sua família ou companheiras, para a construção de seu legado.

A luta contra a discriminação e os preconceitos também é objeto de atenção das educadoras nas relações que acontecem em outros tempos e espaços da rotina das crianças, como as brincadeiras no parque, as refeições, etc. Além disso, a unidade escolar faz a escolha por nomear todas as servidoras da escola (incluindo da limpeza, da cozinha, da secretaria, etc.) como educadoras. Essa opção, mais do que a mudança simbólica de nome, reafirma que uma educação antirracista precisa desestabilizar a simbologia pautada na estrutura racista, que posiciona cada sujeito em um determinado local sem possibilidade de transgressão. A participação dessas outras educadoras é prevista, conforme a possibilidade, nas formações e reuniões pedagógicas, e em situações didáticas e rodas de conversa com as crianças. Por fim, ao envolver as famílias e a comunidade no projeto, por meio de eventos na escola e publicações nas redes sociais, a escola entende que também tem um papel a cumprir na ampliação dessa pauta junto à sociedade.

Respeito às diferenças e valorização da diversidade e da pluralidade - Para que a diversidade seja valorizada e respeitada, é preciso promover o encontro entre modos 
diferentes de existir (ver também a categoria seguinte, Currículo diverso e decolonial). E para que as diferenças sejam efetivamente respeitadas no processo pedagógico é preciso considerar cada criança em sua singularidade, sem limitar as experiências que podem ter e os conhecimentos que podem construir em razão de concepções preconceituosas (como, por exemplo, papéis padronizados de gênero). Reconhecer que há diversidade de trajetórias de desenvolvimento, respeitando os diferentes ritmos e necessidades, é imprescindível para permitir que os sujeitos também criem significados e maneiras próprias de ler o mundo. Considerando que a convivência na pluralidade amplia as possibilidades de aprender, a escola também opta por trabalhar com agrupamentos multietários (crianças de 4 a 6 anos compondo a mesma turma).

Currículo diverso e decolonial - Oferecer às crianças o conhecimento e a cultura construídos historicamente por uma perspectiva representativa e multicultural, isto é, não se limitando ao conhecimento oficial que representa a cultura dos grupos dominantes (Apple, 2014). As marcas da intencionalidade por uma educação antirracista e a favor das diferenças estão presentes desde as paredes e ambientações dos territórios da escola, que buscam descolonizar a estética habitualmente permeada pela hegemonia branca - trazendo nos brinquedos, acervos literários e itens decorativos elementos que fazem referências às culturas africanas e afro-brasileiras - até as escolhas curriculares pelas temáticas que serão estudadas pelas crianças - que preveem, por exemplo, a presença das famílias protagonizando momentos de troca de saberes junto das crianças e de intelectuais negras nos momentos formativos com as educadoras.

Escuta atenta às crianças - $\mathrm{O}$ trabalho pedagógico é construído levando em consideração as perspectivas, interesses e preferências das crianças, o que requer atenção não apenas à fala, mas também ao choro, às atitudes e outras formas de expressão. Isso não significa transformá-las em critério soberano na tomada de decisões, mas compreender que a educação, principalmente aquela que se pretende antirracista e é inspirada em valores como o comunitarismo e a coletividade, considera todos os sujeitos que dela fazem parte. Deste modo, tais expressões são carregadas de indicações sobre como as crianças pensam a escola e os demais lugares que frequentam, as relações tecidas nesses espaços e as temáticas investigadas nos projetos. Essa escuta é um valioso subsídio para que as professoras possam planejar ações e propostas com uma intencionalidade pedagógica que considere interesses e necessidades das crianças e ampliem e aprofundem os seus conhecimentos.

Protagonismo das crianças - Reconhecer o papel ativo das crianças na construção de seu conhecimento e na produção de cultura. Para isso, valorizar os saberes que já possuem, criando oportunidades para compartilharem experiências. A participação das crianças não se dá apenas no desenvolvimento dos projetos didáticos, mas também nos assuntos e decisões da escola, por meio de projetos como Diretor e Diretora de escola por um dia ${ }^{15}$ e as assembleias infantis, práticas que fazem parte do princípio de gestão democrática presente no PPP da unidade.

Ludicidade e fantasia - Além de fortalecer a dimensão afetiva das práticas pedagógicas, tornam possível abordar problemáticas das relações étnico-raciais e de gênero com as crianças pequenas. Destaca-se, em especial, a estratégia das figuras de afeto, já mencionadas. 
Na narrativa de 2018, por exemplo, a Família Abayomi embarcou em uma viagem e trouxe consigo muitos elementos que faziam referência à vida de Nelson Mandela, como livros, objetos, imagens e fotografias que instigaram as crianças a iniciarem as investigações acerca de sua vida e das lutas que travou contra o racismo e o apartheid na África do Sul. A partir de então, as temáticas foram sendo trabalhadas com as crianças pela mediação desses personagens. Além de fazerem parte das histórias que conduzem os projetos didáticos, as figuras de afeto também são envolvidas nas situações cotidianas da escola para problematizar conflitos e propor reflexões sobre a convivência: as questões são projetadas nos personagens, permitindo a discussão pelo grupo sem expor as situações particulares. Para que isso aconteça, todos os adultos da escola precisam estar atentos e envolvidos para participar do jogo simbólico.

Relação com as famílias - Uma estratégia central do projeto pedagógico é estreitar os laços entre as famílias e a escola, não apenas para a realização de ações e eventos pontuais, mas também criando oportunidades para que a família se envolva ativamente na educação escolar de seus filhos e filhas. Além das reuniões de Conselho de Escola e Associação de Pais e Mestres, a escola inclui no calendário reuniões com a comunidade escolar para apresentar e avaliar os projetos realizados, discutir a proposta educacional da unidade e oferecer espaços de formação para que as famílias ampliem seu repertório sobre os temas trabalhados na escola e sejam incentivadas a discuti-los junto às crianças. A proximidade com as famílias estabelece vínculos afetivos e permite conhecer os talentos presentes na comunidade, convidando-os para contribuir no trabalho pedagógico (ex: oferecer formações para as educadoras, realizar atividades diferenciadas com as crianças, melhorar o espaço físico da escola, etc.).

Avaliar o trabalho pedagógico e o desenvolvimento das crianças - A avaliação é feita principalmente por meio da observação e registro nas diversas documentações pedagógicas construídas pela unidade escolar: semanário, diário de projeto (portfólio da turma), portfólios virtuais (fotografias e vídeos nas redes sociais), caderno de registro (portfólio das crianças). Tem como referência a própria criança e seu processo de desenvolvimento, e não a comparação entre elas. Visa construir uma narrativa sobre o trabalho pedagógico realizado e seus efeitos na aprendizagem das crianças, favorecendo a reflexão sobre o trabalho docente e a tomada de decisões. Os registros sobre cada criança, que são sintetizados em um relatório escrito pela professora, acompanham sua vida escolar e são encaminhados para a outra escola quando fazem a transição para o Ensino Fundamental e contribuem para garantir a continuidade de seus processos de aprendizagem e desenvolvimento.

\section{Análise: um projeto antirracista na pandemia}

A partir das categorias relacionadas à proposta antirracista da escola, sintetizadas anteriormente, discutiremos de que forma esses aspectos têm sido trabalhados no período da pandemia de COVID-19 via ensino remoto no ano de 2020. Assim como a compreensão científica sobre a propagação do novo coronavírus e suas implicações para a sociedade se 
deu por meio de fases, o desenvolvimento do trabalho remoto na escola também ocorreu em etapas com características e abordagens diferentes, construídas com base em contínuas reflexões da equipe sobre a experiência constituída, considerando também as informações e perspectivas de conjuntura disponíveis em cada momento. A análise, portanto, precisa ser contextualizada ao longo de uma narrativa sobre o período, que organizamos em quatro fases marcadas por características específicas.

\section{Primeira fase: manter os vínculos}

Quando as autoridades de saúde reconheceram o imperativo das medidas de isolamento social para conter o avanço da pandemia, a primeira medida adotada pela Secretaria Municipal de Educação de São Paulo (SME) foi anunciar a antecipação do recesso escolar ${ }^{16}$. Não se tinha uma dimensão precisa, àquele momento, de por quanto tempo as escolas precisariam permanecer fechadas - poucos imaginavam que seria por um intervalo tão longo. Como era um período em que as crianças tinham acabado de chegar para o início do ano letivo, e a maioria delas estava iniciando seu processo de acolhimento na escola ${ }^{17}$, uma das mães entrou em contato com a diretora e sugeriu que as professoras disponibilizassem atividades pelas redes sociais para manter, de alguma forma, o vínculo com as crianças. No grupo docente, várias professoras acolheram a sugestão e se mobilizaram para produzir vídeos para as redes sociais da escola (Facebook e Instagram) - voluntariamente, uma vez que estavam oficialmente em recesso.

Assim, a preocupação com a manutenção do vínculo das crianças com a escola, que na educação infantil deve ser compreendido como conteúdo, foi o elemento que impulsionou as ações da equipe. Diante da imposição do afastamento físico, elas decidiram intensificar o uso de estratégias de comunicação, que já utilizam há muito tempo: as redes sociais. (NASCIMENTO, 2020, p. 3, grifo nosso).

As propostas daquele momento não tinham como objetivo desenvolver um projeto didático. Não se considerava aquele trabalho como uma forma de ensino remoto. No primeiro vídeo produzido durante a quarentena, publicado nas redes sociais em 24 de março, uma das professoras grava um recado afetuoso para as crianças, avisando que a partir de então estariam fazendo vídeos como forma de estarem mais próximas, e convida as crianças a fazerem o mesmo ${ }^{18}$. Outras professoras também gravaram vídeos nessa esteira, contando histórias, cantando músicas e propondo atividades para serem feitas em casa. Foram publicados vídeos todos os dias, inclusive aos sábados e domingos, durante o recesso de três semanas $^{19}$. O princípio da Relação com as famílias, considerado fundamental no projeto pedagógico da escola, evidencia-se aqui como decisivo para efetivar a proposta, uma vez que o acesso de crianças pequenas às redes sociais não é direto, mas mediado por familiares mais velhos. Sem um vínculo preestabelecido - inclusive pelo aspecto objetivo de os familiares 
estarem conectados às páginas da escola nas redes - não seria possível manter esse tipo de contato.

A antecipação do recesso escolar também pode ser considerada uma estratégia da SME para ganhar tempo enquanto outras soluções eram elaboradas, uma vez que a perspectiva do retorno de fato às atividades presenciais logo se mostrou difícil de definir. Em 08 de abril, a SME anunciou as diretrizes para assegurar a aprendizagem dos estudantes da rede após o final do recesso, pelo tempo que o atendimento presencial continuasse suspenso ${ }^{20}$. A instrução normativa determinou que o processo de aprendizagem deveria ocorrer prioritariamente por meio de material impresso, e apenas de forma complementar em ambiente virtual, para que os estudantes sem acesso às atividades remotas não fossem prejudicados. O material impresso seria elaborado pela Coordenadoria Pedagógica (COPED) da SME e enviado para a casa dos estudantes, com previsão para ser utilizado por dois meses. De que forma as propostas remotas da escola deveriam dialogar com o material, entretanto, ficou à critério de cada unidade, uma vez que não havia livro do professor ou orientações pedagógicas específicas vindas da rede municipal.

O dia 13 de abril foi a data prevista para o início oficial das atividades remotas, tendo como base o livro "Trilhas de Aprendizagens", material didático desenvolvido pela SME para ser enviado à casa das crianças. Enquanto isso, nas reuniões pedagógicas virtuais, o grupo estudava as propostas do livro, constatando que iam ao encontro do que já vinha sendo feito nos vídeos desde o início do recesso: contação de histórias, experiências culinárias, brincadeiras, produções artísticas, etc. Portanto, o marco oficial de início não representou mudanças significativas no trabalho que vinha sendo desenvolvido.

\section{Segunda fase: repensar o trabalho, reencontrar os princípios}

Passados quase um mês de trabalho desde a publicação do primeiro vídeo, o grupo sentiu que era o momento de repensar a atuação. Para grande parte das professoras, que do dia para a noite tiveram que se transformar em youtubers (NASCIMENTO, 2020), o sentimento inicial de entusiasmo e engajamento começava a dar lugar à exaustão.

O cansaço mental que traz ficar horas olhando para uma tela, gravando e regravando, porque você erra e tem que voltar o vídeo, e tentar de novo, e decorar texto... É um processo muito exaustivo. (...) Para mim, era muito melhor eu sair da minha casa, pegar dois ônibus, ir para a escola, ficar seis horas inteiras lá, depois pegar dois ônibus para voltar, do que fazer esse trabalho daqui da minha casa. (Professora Solange, entrevista em 25/08/20)

A Carta Aberta para a Comunidade da EMEI Nelson Mandela ${ }^{21}$, publicada em forma de vídeo pelas educadoras em 22 de abril, marca o início da segunda fase do trabalho realizado durante a pandemia. Na Carta, comunicam suas expectativas em relação ao trabalho remoto que, ao que tudo indicava, iria se prolongar; reafirmam os princípios que orientam a 
concepção pedagógica da escola e expressam a opção por uma abordagem que cuide também da saúde mental de todos:

(...) Não desejamos com os nossos vídeos e postagens compensar ou recuperar o que seria vivido na escola, uma vez que isso é impossível nesse momento e que tal tentativa não faria parte do que acreditamos ser uma Educação Infantil de qualidade.

Também não queremos indicar uma lista de atividades que devem ser seguidas à risca para entreter as crianças, e muito menos que vocês, familiares, se tornem professores ou professoras. Nosso intuito é sugerir e indicar caminhos para que mergulhem no universo da infância. Não há outra maneira para isso que não seja escutando as crianças, as acolhendo e permitindo que sejam nossas guias nesse oceano de possibilidades.

Sabemos que estamos em um momento difícil para todas e todos. (...) Por isso: Calma! Se tem dias que você não quer fazer nada, tudo bem! Esses momentos de ócio também são importantes e precisam acontecer. (Carta Aberta para a Comunidade da EMEI Nelson Mandela, 22 de abril de 2020)

A Carta também sinaliza o novo rumo que o conteúdo publicado tomaria, cada vez mais consonante com as temáticas e os valores que inspiram o projeto da escola:

Nossa escola tem como nome e patrono Nelson Mandela - o líder sul-africano que dedicou sua vida a causas humanitárias - e nosso projeto preza pelo respeito, pelo cuidado com o outro e é realizado de acordo com valores inspirados nas sociedades africanas e afro-brasileiras, como o comunitarismo e a coletividade. Por isso, gostaríamos de dizer mais uma vez para todos aqueles que puderem, permanecerem em casa, cuidando assim de quem está perto e de quem está longe e contribuindo para que essa doença não se propague cada vez mais. (Carta Aberta para a Comunidade da EMEI Nelson Mandela, 22 de abril de 2020)

Educadoras representando todos os segmentos da escola aparecem na gravação, cada qual lendo um trecho da mensagem. Essa escolha reflete o princípio da Luta contra o racismo e a discriminação, que considera imprescindível compreender todos os adultos do quadro de funcionários como educadores em um currículo que se pretende antirracista. Além disso, o vídeo da Carta inaugura as produções coletivas: a partir de então, o conteúdo publicado nas redes sociais deixa de ser o trabalho individual das professoras e passa a ser uma criação em parceria. Formaram-se quatro grupos para elaborar conjuntamente e gravar as propostas, e algumas professoras que tinham habilidade com edição de vídeo se encarregaram de fazê-la para todo o conteúdo.

O Respeito às diferenças e valorização da diversidade e da pluralidade também precisa se aplicar ao trabalho docente coletivo. No momento inicial da divisão dos grupos de trabalho, isso foi um grande desafio. Isso porque foram feitos grupos compostos apenas por professoras antigas - que já estão familiarizadas com as concepções do PPP da escola - e grupos apenas de professoras que tinham acabado de ingressar na unidade. Esse cenário fez 
com que a produção dos conteúdos dos vídeos e as concepções presentes na sua elaboração divergissem muito de um grupo para o outro, causando conflitos entre a equipe. $\mathrm{O}$ ocorrido trouxe a necessidade da reformulação desses grupos, os organizando em um segundo momento de outro modo, para que professoras antigas e mais novas, com habilidades, experiências e formas de contribuir diferentes pudessem trabalhar juntas e aprender umas com as outras.

A programação das atividades propostas para a semana começou a ser publicada no domingo: as histórias a serem contadas, os brinquedos a serem confeccionados, os jogos e brincadeiras a serem ensinados. Em uma das postagens desse período, as educadoras ensinam uma brincadeira com copos, substituindo o verso "escravos de jó" da cantiga tradicional por "guerreiros nagô"22, inspiradas nas formações da educadora Kiusam de Oliveira ${ }^{23}$. A educadora viu a postagem e publicou um comentário:

Olá. Achei linda a brincadeira, mas a cantiga guerreira nago que eu ensino não é essa cantada na brincadeira. A que eu aprendi a 23 anos atrás e saio espalhando nas formações de professores pelo país, tem "gira, salta e deixa Zambele (ou Canjere) ficar". Aí, o que foi modificado só as duas primeiras linhas da estrofe! Contudo, bora lá, aprendendo a cantiga correta é mudança de paradigma na certa! Arrasem!!! $\bigcirc$ (Kiusam de Oliveira, comentário no Instagram em $06 / 05 / 20$, grifo nosso). ${ }^{24}$

A escola, então, publicou uma errata com o comentário da formadora e, dias depois, colocou nas redes um novo vídeo, no qual apresenta a versão inteiramente ressignificada da cantiga a partir das observações de Kiusam. A importância das mudanças não pode ser subestimada: as vivências proporcionadas pela Educação Infantil formam memórias afetivas e são decisivas na construção da identidade das crianças (Silva; Urt, 2016). Em entrevista, a professora Solange, uma das responsáveis pela atividade com a cantiga, relata que várias gerações - incluindo a dela própria - foram educadas entre brincadeiras e cantigas que traziam o racismo e a violência racial de forma naturalizada: "plantei uma florzinha no meu quintal / nasceu uma neguinha de fio dental / dança neguinha / eu não sei dançar / pega o chicote que ela dança já" 25 e "barra-manteiga / na fuça da nega / minha mãe / mandou bater / nessa daqui" são alguns dos exemplos.

Solange reconhece que, ao longo das diversas formações pedagógicas pelas quais a escola passou desde que iniciou seu projeto sobre as relações étnico-raciais, o grupo de educadoras compreendeu que "na educação antirracista, o movimento é exatamente esse: parar, refletir, ressignificar, abandonar práticas e criar novas" ${ }^{\prime 26}$. Se uma cantiga estiver em contradição com os valores ético-políticos do projeto pedagógico e não puder ser ressignificada, é melhor que seja abandonada. No caso da cantiga "Escravos de Jó", a estratégia da ressignificação pareceu uma escolha mais acertada, pois trata-se de mudar a forma como a negritude é apresentada às crianças. Pelo aspecto da Luta contra o racismo e a discriminação, o currículo que aborda as pessoas negras do Brasil apenas pelo histórico de sofrimento e opressão (escravização) comete o equívoco de ignorar o legado de resistência e 
riqueza cultural; mais do que apenas trocar a letra, a opção por cantar "Guerreiros Nagô" é mudança de paradigma na certa.

A cada semana, o trabalho remoto realizado pelas educadoras da EMEI Nelson Mandela amadurecia; entretanto, a forma como as estatísticas das redes sociais são disponibilizadas não permitia saber quantas famílias efetivamente estavam acessando o conteúdo - os números mesclam visualizações feitas pela própria equipe da escola e por pessoas de fora que também seguem as páginas. Pelos nomes que apareciam nos comentários e "curtidas", a equipe percebeu que só as redes sociais não seriam suficientes para alcançar as famílias de todas as 212 crianças matriculadas (NASCIMENTO, 2020).

Em busca de criar novos canais de comunicação, em 23 de abril a escola iniciou uma conta institucional de WhatsApp e começou a divulgá-la. Porém, em vez de assuntos pedagógicos, a maior parte dos contatos que chegavam a esse canal eram perguntas sobre o cartão alimentação. Este foi um dos fatores que sinalizou, para a equipe, a necessidade de fazer um mapeamento para saber não apenas se as famílias estavam acessando o conteúdo que a escola produzia, mas também como estavam lidando com a pandemia.

No dia 01 de maio a escola publicou um questionário ${ }^{27}$ no Facebook; passada uma semana, porém, apenas um terço das famílias havia respondido. Das 68 respostas recebidas no período, 56 famílias $(82,3 \%)$ disseram ter sofrido diminuição de renda desde o início da pandemia e, dentre estas, $20(35,7 \%)$ afirmaram estar privadas de itens básicos em casa. Como ainda não havia previsão de fornecimento de cestas básicas por parte do governo, a equipe escolar se mobilizou para arrecadar mantimentos e distribuí-los periodicamente às famílias, ação que permanece acontecendo até o momento em que este texto é escrito ${ }^{28}$. É possível reconhecer, aqui, uma das manifestações práticas da coletividade e do comunitarismo, valores presentes nas culturas africanas e afrobrasileiras que inspiram o projeto da escola. E para tentar, enfim, estabelecer contato com os outros dois terços das famílias, as educadoras se organizaram para localizar os números de telefone dos responsáveis de todas as crianças nas fichas de matrícula e ligar para cada um. Começaram, então, a formar grupos de WhatsApp, um para cada turma, com as professoras e os familiares.

\section{Terceira fase: construir um projeto em diálogo com as crianças e famílias}

Na primeira fase, a característica eram as produções individuais com a finalidade de manter o vínculo das crianças com as professoras; na segunda, foi a produção coletiva e mais sintonizada com o projeto pedagógico da escola. Embora a passagem tenha representado um avanço importante, a melhora foi no campo da produção; faltava, ainda, a dimensão da escuta para que as propostas estivessem coerentes com o princípio do Protagonismo das crianças. A valorização dos saberes das crianças e o compartilhamento de experiências, necessários para que tenham papel ativo na produção de cultura e na construção de seus conhecimentos, é um movimento natural de se fazer em uma roda de conversa na escola, quando há intencionalidade pedagógica para tal; todavia, essa mesma prática se torna quase inviável por meio das redes sociais, em grande parte devido a uma característica desse tipo de mídia: o 
fluxo de informação que privilegia a postagem e limita a interação ao âmbito restrito dos comentários e curtidas. O relato da professora Solange explicita esses dilemas:

No começo as nossas propostas estavam muito dentro dessa coisa do "fazer": a gente fazia a proposta, as crianças faziam, e não tinha algo que sempre criamos e cultivamos na escola: ouvir a fala das crianças, a participação delas nos encaminhamentos do projeto. Não tínhamos isso no começo [do trabalho remoto], e a gente entrou em crise. Achamos que a nossa página virou uma "página de atividades"! E isso foi deixando a gente muito inquieta... No decorrer desse trabalho à distância a gente foi pensando e se questionando como aproximar essas propostas do nosso fazer na escola. Foi preciso dar esse passo além. E não tinha outro jeito senão ouvir as crianças. (Professora Solange, entrevista em 25/08/20)

Algumas famílias deixavam comentários no Instagram e no Facebook; outras chegavam a compartilhar fotos e vídeos da participação das crianças nas atividades, que depois eram compilados em postagens nas redes da escola. Contudo, o princípio da Escuta atenta às crianças vai além de abrir espaço para a expressão, e implica sobretudo em levá-la em consideração no planejamento de propostas e na construção do trabalho pedagógico.

A criação dos grupos de WhatsApp por turma, que ocorreu na semana do dia 18 de maio, marca o início da terceira fase do trabalho remoto, pois a partir de então foi possível manter uma relação de mão dupla com as crianças. Os grupos representaram um espaço de diálogo mais próximo, apenas com as professoras da turma e suas crianças (pela mediação das famílias), e não a escola inteira; possibilitaram uma comunicação mais dinâmica e interativa, por meio de formatos diversos, como áudio, foto e vídeo. Um outro fator, ligado à realidade socioeconômica brasileira, também influenciou fortemente esse resultado: dos cidadãos das classes D e E com acesso à internet, $85 \%$ fazem o uso exclusivamente pelo celular e com pacotes de dados limitados (SOPRANA, 2020). E praticamente todas as operadoras de celular oferecem planos pré-pagos com WhatsApp grátis, isto é, sem consumir a franquia de dados, o que torna o aplicativo da plataforma preferencial para consumo de conteúdo.

Embora ideal por muitos aspectos, também há contradições presentes em estar em um grupo de WhatsApp com as famílias: exige das professoras um envolvimento que vai além da atribuição. Implica ter o número pessoal de celular exposto e o contato direto com as famílias a qualquer momento, fora do contexto habitual de trabalho. Uma demanda extra sobre o tempo e a privacidade, além do que já havia sido acrescentado pelas redes sociais da escola e plataformas oficiais da prefeitura durante o período de isolamento social. A professora Solange relata que, por não ter o hábito de interagir em grupos virtuais, combinou com sua parceira de turma que ficaria responsável pelas outras frentes, enquanto a colega cuidaria do WhatsApp. Sua parceira compartilhava com ela algumas das mensagens que recebiam, até que uma das falas das crianças provocou um choque que levou Solange a repensar seu posicionamento:

Um dia ela me encaminhou o áudio de uma criança do grupo: (...) “Oi, bom dia prô Marina! E a prô Sol, ela morreu?”. Aquilo, pra mim, me pegou de um jeito, 
muito, muito... eu comecei a chorar. (...) E foi uma criança que entrou esse ano na escola. Não era nenhuma criança do ano passado que já me conhecia, que já tinha um vínculo comigo, pra sentir falta de mim. (...) Eu pensei: as crianças estão vivendo a mesma pandemia que nós. As notícias das pessoas morrendo, pessoas até próximas a elas podem ter morrido. E ela não me vê ali no grupo, o que ela pensou? A prô Sol morreu. Isso foi algo que me chacoalhou. (...) Eu tenho que estar nesse grupo, presente também. Eu tenho que vencer esse desafio particular, individual, para estar ali. (Professora Solange, entrevista em 25/08/20).

Nem todas as professoras da unidade, porém, quiseram ter seus números divulgados para as famílias; algumas optaram por não participar desse movimento de criação e interação pelos grupos de WhatsApp, uma vez que ele não fazia parte das ferramentas de comunicação com as famílias indicadas oficialmente pela SME. Essa escolha teve que ser respeitada pela gestão e por todas as educadoras. Nas turmas em que esse foi o caso, uma professora fazia a comunicação pelo WhatsApp enquanto sua parceira alimentava as plataformas oficiais, como o Google Sala de Aula ${ }^{29}$.

O mês de maio estava chegando ao fim, e com o estabelecimento de contato por WhatsApp, o questionário já havia recebido respostas de dois terços das famílias. Um dos itens do formulário perguntava se o caderno Trilhas de Aprendizagens, produzido pela SME, já havia chegado até a casa da pessoa. Em 24 de maio, de um total de 134 respostas, apenas 8 assinalavam que $\operatorname{sim}(5,9 \%)^{30}$ - uma parcela extremamente pequena, considerando que as escolas foram instruídas para usar o material como referência principal de suas atividades a partir de 13 de abril.

Nas reuniões pedagógicas virtuais, algumas professoras manifestavam incômodo pela falta de uma unidade que conectasse as propostas dos vídeos, algo sempre prezado nos projetos didáticos da escola. Embora os vídeos apresentassem propostas interessantes, não estavam construindo uma narrativa. Não seria possível, de qualquer modo, fazer um trabalho remoto em diálogo com o caderno Trilhas de Aprendizagens, porque o material impresso não estava chegando para as famílias. Diante desse cenário, as educadoras decidiram começar a construção de um projeto didático fundamentado no PPP da escola, como já estava planejado antes das atividades presenciais serem interrompidas. $\mathrm{O}$ desafio seria realizá-lo de forma virtual, pela primeira vez.

Na EMEI Nelson Mandela, o ciclo do trabalho por projetos se inicia a cada ano com a chegada da família Abayomi que, após um período de férias, volta de viagem trazendo uma mala com muitos elementos que serão disparadores do projeto didático. A narrativa inicial é construída pelas professoras, conforme o tema estabelecido para o projeto do ano, e vai sendo desenvolvida a partir dos questionamentos e falas das crianças.

Imagine que cada turma é um barco prestes a partir para uma longa jornada de um ano em alto mar, em busca de grandes tesouros. Cada embarcação será livre para traçar sua própria rota em busca desses tesouros, mas receberá um mapa com importantes pontos de referência que não podem deixar de serem vistos nessa viagem. É possível que em um primeiro momento as embarcações prefiram seguir 
juntas para se sentirem mais seguras e confiantes, mas aos poucos vão criando forças e autonomia para projetarem seus próprios roteiros. E quem será responsável por definir e redefinir esse roteiro ao longo do caminho? Com certeza serão os tripulantes desse barco, com seus olhares, opiniões, respostas e falas. Em determinados momentos da viagem, é comum que os navegantes das diferentes embarcações queiram se encontrar para compartilhar os tesouros que descobriram pelos diferentes trajetos que seguiram. E é nessa hora que percebem que por mais que estejam seguindo seus próprios roteiros, estão todos unidos por uma mesma motivação (EMEI nelson mandela, 2019, p. 85).

Dessa forma, a Ludicidade e fantasia são o ponto de partida. Em 25 de maio, a postagem trazia uma foto de Dayó e Henrique, figuras de afeto da família Abayomi, revendo suas recordações sobre a viagem que fizeram à região Nordeste - narrativa que seria apresentada às crianças no início do ano, mas acabou não acontecendo por conta da pandemia. A questão feita às meninas e aos meninos a partir da foto foi: "Vocês sabem que lugar é esse? O que sabem sobre ele? Mandem suas respostas aqui pra gente!"’31. E assim estava disparado o início do projeto. Imediatamente as famílias começaram a dar o retorno pelos grupos de WhatsApp, enviando as falas das crianças em forma de áudio e vídeo, e a publicação do dia seguinte foi uma compilação dessas participações, que trazia a leitura e as hipóteses das crianças sobre os elementos que compunham as imagens. Nas publicações seguintes, as professoras buscaram, a partir das respostas recebidas, ampliar e aprofundar os conhecimentos das crianças acerca dos estados da região Nordeste; trouxeram elementos da cultura nordestina como cordel, xilogravura e forró, entre outros. Além disso, notaram uma grande participação das famílias, uma vez que muitas vieram do Nordeste, e o Centro de Tradições Nordestinas $(\mathrm{CTN})^{32}$, que fica no mesmo bairro da escola, foi mencionado em várias falas.

Enquanto isso, o mês de maio era marcado por episódios de violência associada ao racismo no Brasil e no mundo. Em 18 de maio, uma operação policial na região metropolitana do Rio de Janeiro fez mais de 70 disparos contra uma casa e matou o adolescente João Pedro, de 14 anos - um jovem negro pobre, como a maior parte das vítimas da letalidade policial (DUPAS; ROMERO, 2018; LEMOS Et Al., 2017). Em 25 de maio, uma abordagem da polícia em Minneapolis (Estados Unidos) asfixiou covardemente o vigilante negro George Floyd; a partir de então, uma série de protestos tomou conta das ruas nos EUA e em outros lugares do mundo, proclamando uma vez mais o lema "Black Lives Matter"33 e exigindo o fim do extermínio da população negra pela violência do Estado. Tendo a Luta contra o racismo e a discriminação como um dos eixos principais de seu PPP, a EMEI Nelson Mandela entendeu que a sua responsabilidade ia além do trabalho pedagógico cotidiano e abarcava também a ampliação desse debate junto à comunidade. No dia 01 de junho a escola fez uma postagem posicionando-se como uma instituição que se propõe a construir um currículo antirracista e afrocentrado, e trazendo fotos de uma ação realizada com as crianças. Nesta semana, a escola fez uma publicação diária sobre educação antirracista - além das publicações diárias do projeto didático -, compartilhando com a comunidade as reflexões da unidade sobre concepções e práticas pedagógicas. 


\section{Quarta fase: por um tempo, a consolidação das propostas}

Considerando o desenvolvimento do projeto didático e as reflexões sobre a educação antirracista como as duas frentes principais de seu trabalho remoto, a equipe docente passou a organizar, a partir de 08 de junho, uma rotina muito bem definida de produção e publicação de conteúdo. Este é o marco inicial da quarta fase, que durou dois meses e meio, sendo a mais longa e constante do período de trabalho remoto até então. Segundas, quartas e sextas a escola fazia uma publicação relacionada ao projeto didático, e às terças e quintas, sobre a educação antirracista. A escolha por essa periodicidade considerou que o maior espaçamento das propostas didáticas aliviaria as famílias, que já tinham múltiplas necessidades para conciliar, e também as professoras, que estavam sobrecarregadas pelo ritmo de produção de conteúdo autoral. A menor demanda sobre as famílias também favoreceria a participação mais consistente. O envolvimento destas no processo era, ao mesmo tempo, imprescindível - pois as crianças não têm autonomia para acessar o conteúdo sozinhas - e oportuno, pois convida os adultos a também refletirem sobre as problemáticas.

O princípio do Currículo diverso e decolonial esteve presente não apenas no conteúdo, mas intencionalmente refletido também na estética das produções, que fazia referência a culturas africanas, afro-brasileiras, indígenas e latinas - daquelas, enfim, ao Sul do globo (OLIVEIRA; CANDAU, 2010). As representações davam preferências aos corpos, aos personagens, às formas artísticas e à simbologia não hegemônicos.

O percurso sobre a temática do Nordeste, desenvolvido ao longo de cinco semanas, com um total de 15 vídeos, buscou ampliar e aprofundar os conhecimentos da região e de seus elementos culturais, incluindo propostas artísticas e vivenciais para se fazer em casa. Foi finalizado em 26 de junho, com um vídeo produzido a partir das contribuições enviadas pelas crianças e suas famílias. Teve, do começo ao fim, a marca dos projetos coletivos, que envolvem todas as turmas da escola, como é característico dos projetos didáticos desenvolvidos na unidade todos os anos. A equipe docente começou, então, a elaborar o próximo percurso narrativo, mantendo as mesmas marcas. Em uma reunião pedagógica, as professoras notaram que a capoeira apareceu nas falas de algumas crianças sobre o Nordeste, e poderia ser um potente fio condutor para a continuidade do trabalho; em 29 de junho publicaram um vídeo sugerindo que as crianças pesquisassem e fizessem suas produções inspiradas nessa prática corporal.

O percurso de estudo sobre a Capoeira foi realizado ao longo de nove semanas, em um total de 16 vídeos, que incluíram contação de histórias e leituras de livros com a temática da capoeira; aprofundamento sobre a história da capoeira no Brasil e suas implicações sociais; propostas de pesquisas, de desenhos inspirados em obras que retratam a capoeira, de confecção de um Berimbau com materiais caseiros e de vivências inspiradas na gestualidade da capoeira. Os registros enviados pelas famílias revelam muitas crianças jogando capoeira com seus irmãos mais velhos ou com seus pais, mostrando mais uma vez o reconhecimento do patrimônio cultural corporal da comunidade (NEIRA, 2019). As professoras também 
entenderam a importância de trazer para esses vídeos representantes da capoeira, e conseguiram o contato de mestres e mestras da Bahia, do Rio de Janeiro e de São Paulo, que gentilmente gravaram entrevistas e depoimentos narrando seu envolvimento com a prática corporal. Presenças e vozes não hegemônicas, que têm dificuldade para encontrar espaço na educação escolar, tiveram espaço e reconhecimento para compartilhar seus saberes e os valores afro-brasileiros, como ancestralidade e memória; os corpos negros e a cultura afro se fizeram representar. O projeto se encerrou em 19 de agosto, em uma vivência online realizada pelo Mestre Piter para as meninas e meninos da escola.

A série de postagens intitulada "Reflexões e práticas Mandelenses para uma educação antirracista na escola", direcionada aos adultos, trouxe um total de 13 publicações ${ }^{34}$, abordando temas como: o que é educação antirracista, como se dá a formação das educadoras e da equipe escolar, atitudes racistas que crianças pequenas podem ter, o trabalho com figuras de afeto, o papel da gestão, práticas democráticas, tons de pele em giz e lápis, a lei 10.639/03, a coletividade nos projetos didáticos e a representatividade no espaço escolar.

Outra prática desta fase foram os encontros virtuais entre professoras e crianças, que passaram a acontecer cerca de uma vez por semana, pelo Google Meet. A ideia surgiu após a sugestão de uma família na reunião virtual do Conselho de Escola. Nesses encontros estão presentes, em média, de oito até dez crianças; elas têm oportunidade de ver e conversar com os amigos e amigas de maneira síncrona, e as professoras sugerem propostas para que possam interagir. As contações de histórias, jogos de bingo de números e letras e outras brincadeiras, relacionadas ou não com o projeto didático, fazem parte desses momentos. Não há um acordo sistematizado para toda a escola de como ou com qual frequência esses encontros devem acontecer, ficando a critério de cada professora tomar essa decisão.

A pandemia não afetou a escola apenas de forma indireta, suspendendo o atendimento presencial e a forma do trabalho pedagógico. Nesse ínterim, a coordenadora pedagógica da escola foi diagnosticada com COVID-19 e precisou ser hospitalizada, chegando a passar 20 dias internada na UTI. E por mais que o trabalho pedagógico remoto tenha se consolidado na quarta fase, pela regularidade das postagens e pelo alinhamento ao PPP, os cinco meses sem pausa transcorridos na quarentena começavam a abater os ânimos de ambos os lados. Agosto chegava ao fim, e as professoras começaram a perceber a participação das crianças e famílias nas atividades esmorecer. Na semana do dia 24 de agosto, a escola publicou uma seleção de conteúdos feitos por terceiros, em vez de conteúdo autoral produzido pelas professoras. Nesse tempo, a equipe avalia o que foi realizado até então, pensa um novo percurso narrativo para o projeto e decide qual será o melhor formato para conduzi-lo.

\section{Considerações finais}

O propósito deste estudo de caso é contribuir para o debate sobre o papel da escola durante e após a pandemia, a partir da trajetória concreta de uma escola pública de educação infantil comprometida com um projeto pedagógico antirracista. As fases descritas na análise não foram, obviamente, premeditadas pela equipe; a periodização, identificada pelo olhar da 
pesquisa sobre a experiência vivida, tem como objetivo reconhecer os processos mais amplos que ocorriam enquanto as decisões cotidianas eram tomadas. A narrativa já expressa, em si, a maior parte dos aprendizados coletivos que o período proporcionou; outros, ensaiando respostas a alguns dos dilemas apresentados no início do texto, estão nas considerações a seguir.

O ensino remoto não deve ser pensado como uma versão virtual da educação presencial, uma vez que as relações, que são a base do processo educativo, não podem se dar da mesma maneira. Estando as relações mediadas por ferramentas tecnológicas, as estratégias para a modalidade remota devem ser (re)construídas sob medida, considerando, por um lado, os princípios que fundamentam a qualidade social da educação e, por outro, a lógica e a linguagem próprias dos meios digitais e os recursos disponíveis. Sobretudo na Educação Infantil, em que a mobilização de afetos e de vivências é parte indissociável do currículo, é impossível fazer pela tela o que se faz na escola. A interação por áudio e vídeo permitiu a escuta da fala das crianças - princípio fundamental do projeto pedagógico -, mas não a escuta dos corpos e a comunicação do toque, parcela importante da expressão de meninas e meninos que ainda estão aprendendo a usar palavras.

Quando o atendimento é presencial, a escola conta com meios para buscar oferecer uma educação de qualidade para todas as crianças. Na EMEI Nelson Mandela, as professoras dispõem de (e são responsáveis por) uma extensa e variada documentação pedagógica que registra os processos de aprendizagem e desenvolvimento da turma como um todo e de cada criança individualmente. A observação faz parte da rotina das professoras e é direcionada por um planejamento que estipula crianças específicas para serem olhadas com especial atenção em cada dia; um método que tem por objetivo impedir que a atenção da educadora se torne seletiva, dirigindo-se às mesmas crianças todos os dias e deixando outras negligenciadas. $\mathrm{O}$ mesmo não é possível na modalidade remota, porque não é possível estabelecer uma relação uniforme com todos. A professora Solange relata:

Estou num grupo de 26 famílias, mas a gente recebe vídeo de quatro ou cinco crianças fazendo as propostas. É um número pequeno. Principalmente agora, que voltou o comércio ${ }^{35}$, caiu a participação "de um jeito" nos grupos... porque as famílias acessam a internet por meio do celular. (...) A mãe ou o pai está trabalhando, o celular está fora de casa. O pai e a mãe chegam tarde, às vezes a criança está dormindo, e vai ver a proposta só no fim de semana. (Professora Solange, entrevista em 25/08/20)

O ensino remoto não consegue alcançar todo mundo. A educação presencial, embora nem sempre alcance a todos o tempo todo, tem meios para oportunizar a participação. No contexto de distanciamento, o contato é incerto; alguns respondem, outros não, e não há como saber, em cada caso, o motivo: se por falta de conectividade, por problemas familiares, por desinteresse ou apenas por inibição. A diretora da escola, Jaqueline, cuja filha também é aluna da unidade, relata a dinâmica que percebe na própria casa: 
Nem sempre isso [baixa participação] é dificuldade com a internet, [ou] descaso das famílias porque a criança não está vendo [os vídeos da escola]. Eu percebo uma dificuldade de a criança interagir com a tela. Eles gostam de tela: gostam de ver TV, de jogo, de ver o vídeo. Mas para eles, conversar com a tela é estranho. (...) Eu falava isso para elas [as professoras]: muitas vezes, quando vocês perceberem que as crianças não estão mandando devolutiva alguma, lembrem da minha [filha]. Ela vê sim, ela olha, ela está absorvendo um monte de coisas, mas mandar um vídeo, tirar uma foto, é uma coisa que ela não deseja, e que eu estou respeitando. (...) Eu acho até legal falar para os pais que eles não precisam forçar nada. (...) Deixa as crianças, vamos entender o quanto está difícil para elas também. (Diretora Jaqueline, entrevista em 26/08/20).

O desafio de estabelecer a comunicação com as famílias foi o princípio. Sem ter conseguido ainda superá-lo completamente, apresentou-se outro ainda maior: o de elaborar propostas remotas que fossem ao encontro da concepção pedagógica e do projeto antirracista da escola. Afinal, o caminho inverso - trazer o projeto da EMEI Nelson Mandela para a modalidade remota - simplesmente não seria possível. A partir das inúmeras e diversas respostas que escolas e sistemas ofereceram à crise, podemos, hoje, olhar para trás e fazer uma avaliação. Quando a crise se instalou, porém, não era possível olhar para frente e saber, ao certo, aonde cada caminho poderia levar. O dilúvio chegou e a Arca de Noé ainda não estava pronta (Cury, 2020). Havia apenas educadoras, uma concepção de educação, a experiência constituída e uma opção ética e política de como se posicionar no mundo. $\mathrm{O}$ propósito de impedir uma ruptura no projeto educacional foi a razão de buscar alternativas, no princípio; os princípios internalizados pelas educadoras foi o que permitiu que até mesmo em práticas remotas se refletisse o projeto educacional, ao longo do percurso.

Portanto, embora o recorte temporal deste estudo de caso diga respeito ao trabalho pedagógico realizado remotamente, no período da pandemia, talvez as reflexões que ele proporcione digam mais ainda sobre o trabalho cotidiano, que a escola desenvolve em tempos normais. Não seria de súbito que se elaborariam propostas virtuais de enfrentamento ao racismo e à discriminação, se a unidade escolar já não tivesse um currículo antirracista consolidado. Do mesmo modo, realizar projetos didáticos coletivos, a partir da escuta das crianças e por meio do ensino remoto, só foi possível porque o grupo docente já tinha experiências construídas, ao longo de anos, com trabalho por projetos na Educação Infantil. Não foi necessário realizar algo que nunca tinha sido feito antes; o desafio foi descobrir - ou inventar -, formas de buscar as mesmas finalidades por meio de telas.

Não obstante todas as inovações produzidas, as educadoras não alimentam a ingênua expectativa de ter alcançado a potência da educação presencial que se faz na escola, nem de estar garantindo plenamente o direito à infância e à educação para todas as crianças. O que fazer com aqueles alunos que não vieram participar da proposta? Ainda buscamos respostas. A pandemia escancarou muitas desigualdades que a escola é impotente para combater. Entretanto, foi um período que igualmente surpreendeu por ter mostrado ser possível enfrentar adversidades maiores do que se supunha. Em um cenário repleto de incertezas e parco de recursos, educadoras - na EMEI Nelson Mandela e alhures - reconheceram que 
cumprir suas atribuições oficiais não seria suficiente. Por opção política e sem serem solicitadas, engajaram-se na busca de caminhos, puderam construir propostas interessantes e aprenderam no percurso. Reconheceram, como Freire, que

Uma das tarefas do educador ou educadora progressista, através da análise política, séria e correta, é desvelar possibilidades, não importam os obstáculos, para a esperança, sem a qual pouco podemos fazer porque dificilmente lutamos, e quando lutamos, enquanto desesperançados ou desesperados, a nossa é uma luta suicida (...) (FREIRE, 2013, p. 10).

\section{E, em nome da resistência, o trabalho continua.}

\section{Notas}

1. Disponível em: <https://novaescola.org.br/conteudo/19087/mudanca-de-rotina-como-se-manter-proximo-das-familiasem-tempos-de-pandemia>. Acesso em: 06 set. 2020.

2. Disponível em: <https://emais.estadao.com.br/noticias/comportamento,professoras-da-emei-nelson-mandela-usaminstagram-para-oferecer-atividades-para-alunos-na-quarentena,70003303938>. Acesso em: 06 set. 2020.

3. Disponível em: 〈https://www.bbc.com/portuguese/brasil-53141863〉. Acesso em: 06 set. 2020.

4. Disponível em: <https://www.facebook.com/emeinelsonmandela/posts/3420707464630427>. Acesso em: 06 set. 2020.

5. Disponível em: <https://www.facebook.com/emeinelsonmandela/posts/3505306002837239>. Acesso em: 06 set. 2020.

6. Realizado pela Câmara Municipal de São Paulo. Disponível em: <http://www.saopaulo.sp.leg.br/premio-paulo-freire2020/>. Acesso em: 06 set. 2020.

7. Tradução livre.

8. O presente trabalho foi realizado com apoio da Coordenação de Aperfeiçoamento de Pessoal de Nível Superior - Brasil (CAPES) - Código de Financiamento 001. This study was financed in part by the Coordenação de Aperfeiçoamento de Pessoal de Nível Superior - Brasil (CAPES) - Finance Code 001.

9. Todas as professoras da unidade e maior parte das servidoras (que também são consideradas educadoras) são mulheres. Por isso, opta-se neste texto por fazer a flexão de gênero sempre no feminino, o que inclui também os homens do grupo.

10. Disponível em: 〈https://www.facebook.com/emeinelsonmandela〉. Acesso em 28 ago. 2020.

11. Disponível em: <https://www.instagram.com/emeinelsonmandela/> Acesso em 30 ago. 2020.

12. A pesquisa tem a aprovação e autorização do Comitê de Ética em Pesquisa da UNICAMP, sob o número de CAAE 18189619.1.0000.8142.

13. Disponível em: 〈https://www.facebook.com/emeinelsonmandela〉. Acesso em 28 ago. 2020.

14. Disponível em: <https://veja.abril.com.br/brasil/muro-de-escola-e-pichado-com-frase-racista/>. Acesso em 28 ago. 2020.

15. Projeto reconhecido com o Prêmio Paulo Freire de Qualidade do Ensino Municipal, da Câmara Municipal de São Paulo, edição 2018. Disponível em: <https://www.saopaulo.sp.leg.br/wp-content/uploads/2019/02/PREMIO_PAULO_ FREIRE_2018_LIVRETO_PROJETOS_WEB.pdf>. Acesso em: 30 ago. 2020.

16. Antecipado para o período de 23 de março a 09 de abril de 2020. Instrução Normativa SME No 13 , de 19 de março de 2020. Disponível em: <http://legislacao.prefeitura.sp.gov.br/leis/instrucao-normativa-secretaria-municipal-deeducacao-sme-13-de-19-de-marco-de-2020>. Acesso em: 30 ago. 2020.

17. De um total de 210 alunos em 2020 , cerca de 150 chegaram à escola neste ano.

18. No início de cada ano letivo, no ato da matrícula, os responsáveis legais pelas crianças assinam um termo de consentimento de uso de imagem para divulgação nas redes sociais da escola (uma vez que estas fazem parte da 
documentação pedagógica - são um portfólio virtual) e também em veículos oficiais da prefeitura, apresentações em seminários e faculdades, etc.

19. Todo o conteúdo citado está disponível nas páginas da EMEI Nelson Mandela no Facebook e no Instagram. Disponível em: 〈https://www.facebook.com/emeinelsonmandela〉. Acesso em: 31 ago. 2020.

20. Instrução Normativa SME $\mathrm{N}^{\circ} 15$, de 8 de abril de 2020. Disponível em: <http://legislacao.prefeitura.sp.gov.br/ leis/instrucao-normativa-secretaria-municipal-de-educacao-sme-15-de-8-de-abril-de-2020>. Acesso em: 30 ago. 2020.

21. Disponível em: <https://www.facebook.com/emeinelsonmandela/videos/846660965744883>. Acesso em: 30 ago. 2020.

22. Disponível em: <https://www.facebook.com/emeinelsonmandela/posts/3190661934301649>. Acesso em: 02 set. 2020.

23. A postagem faz referência ao Instagram da escritora: <https://www.instagram.com/mskiusam/>. Acesso em: 02 set. 2020.

24. Disponível em: <https://www.instagram.com/p/B_2LwegDlqT/>. Acesso em: 02 set. 2020.

25. Outra variante da cantiga tem a letra: "nasceu uma neguinha de avental".

26. Comunicação pessoal, 01 set. 2020.

27. Os dados foram disponibilizados para consulta dos pesquisadores.

28. Início de setembro, 2020.

29. Também conhecido como Google Classroom, foi uma das plataformas oficialmente adotadas pela SME-SP para a realização do trabalho remoto.

30. Este número, referente ao dia 24 de maio, não reflete a situação exata, uma vez que famílias que responderam o questionário no início do mês podem ter recebido o material até a data da apuração.

31. Disponível em: <https://www.facebook.com/emeinelsonmandela/posts/3243457489022093>. Acesso em: 04 set. 2020.

32. Página do CTN: <https://www.ctn.org.br/>. Acesso em: 04 set. 2020.

33. Tem sido traduzido no Brasil como "Vidas Negras Importam" ou "Vidas Pretas Importam".

34. O álbum com todas as publicações, cada qual composta por uma série de quadros, está disponível em: <https://www.facebook.com/media/set/?vanity=emeinelsonmandela\&set=a.3266534900047685>. Acesso em: 06 set. 2020.

35. Referente à retomada gradual das atividades após o período de quarentena.

\section{Referências}

APPLE, Michael W. Democratic education in neoliberal and neoconservative times. International Studies in Sociology of Education, [S. l.], v. 21, n. 1, p. 21-31, 2011. DOI: 10.1080/09620214.2011.543850.

APPLE, Michael W. Official Knowledge: Democratic Education in a Conservative Age. New York: Routledge, 2014. DOI: 10.4324/9780203814383.

BEHAR, Patricia Alejandra. O Ensino Remoto Emergencial e a Educação à Distância. Jornal da Universidade, [S. l.], 2020. Disponível em: https://www.ufrgs.br/coronavirus/base/artigo-o-ensino-remotoemergencial-e-a-educacao-a-distancia. Acesso em: 8 set. 2020.

CURY, Carlos Roberto Jamil. Educação escolar e pandemia. Pedagogia em Ação, [S. l.], v. 13, n. 1, p. 8-16, 2020. Disponível em: http://periodicos.pucminas.br/index.php/pedagogiacao/article/view/23749. Acesso em: 8 set. 2020.

DUPAS, Elaine; ROMERO, Thiago Giovani. Violência no Brasil: as cores que morrem. Libertas: Revista de Pesquisa em Direito, $[S . \quad l],$.$\quad v. 3, \quad$ n. $\quad 2, \quad$ p. $1-9, \quad 2018$. Disponível em: https://www.periodicos.ufop.br/pp/index.php/libertas/article/view/420/1062. Acesso em: 8 set. 2020. 
EMEI NELSON MANDELA. Projeto Político-Pedagógico. São Paulo/SP, 2019.

FERREIRA, Luciana Haddad; BARBOSA, Andreza. Lições de quarentena: limites e possibilidades da atuação docente em época de isolamento social. Praxis Educativa, [S. l.], v. 15, n. e2015483, p. 1-24, 2020. DOI: 10.5212/PraxEduc.v.15.15483.076.

FRANÇA, R. C.; MASELLA, M. B. Escola pública infantil que inova para incluir a todos: a experiência da EMEI Nelson Mandela. In: IX FALA OUTRA ESCOLA, 2019, Campinas. Anais eletrônicos... Campinas: Galoá, 2019. Disponível em: https://proceedings.science/fala-outra-escola-2019/papers/escolapublica-infantil-que-inova-para-incluir-a-todos--a-experiencia-da-emei-nelson-mandela. Acesso em: 28 ago. 2020.

FREIRE, Paulo. Pedagogia da Esperança. Rio de Janeiro: Paz e Terra, 2013.

GONÇALVES, Tathiana; DUARTE, Leonardo de Carvalho. Tematizando as brincadeiras africanas na EMEI Nelson Mandela. In: NEIRA, Marcos Garcia (org.). Escrevivências da Educação Física Cultural. São Paulo: FEUSP, 2020. p. 207-219.

HODGES, Charles; MOORE, Stephanie; LOCKEE, Barb; TRUST, Torrey; BOND, Aaron. The Difference Between Emergency Remote Teaching and Online Learning. Educause Review, [S. l.], 2020. Disponível em: https://er.educause.edu/articles/2020/3/the-difference-between-emergency-remote-teaching-andonline-learning. Acesso em: 26 ago. 2020.

LAGE, Maria. Os softwares tipo CAQDAS e a sua contribuição para a pesquisa qualitativa em educação. ETD - Educação Temática Digital, [S. l.], v. 12, n. 2, p. 42-58, 2011. DOI: 10.20396/etd.v12i2.1187.

LEMOS, Flávia Cristina Silveira; AQUIME, Rafaele Habib Souza; FRANCO, Ana Carolina Farias; PIANI, Pedro Paulo Freire. O extermínio de jovens negros pobres no Brasil: práticas biopolíticas em questão. Pesquisas e Práticas Psicossociais, [S. l.], v. 12, n. 1, p. 164-176, 2017.

MASELLA, Marina Basques; DUARTE, Leonardo de Carvalho. GOOOLLLAAAÇÇOOOOO! Tematizando o futebol na EMEI Nelson Mandela. In: NEIRA, Marcos Garcia (org.). Escrevivências da Educação Física cultural. São Paulo: FEUSP, 2020. p. 174-183.

MORGADO, José Carlos; SOUSA, Joana; PACHECO, José Augusto. Transformações educativas em tempos de pandemia: do confinamento social ao isolamento curricular. Praxis Educativa, [S. l.], v. 15, p. 1-10, 2020. DOI: 10.5212/PraxEduc.v.15.16197.062. Disponível https://www.revistas2.uepg.br/index.php/praxiseducativa/article/view/16197. Acesso em: 8 set. 2020.

NASCIMENTO, Iracema Santos Do. Reforçar vínculos entre os sujeitos e fortalecer a autonomia da escola para enfrentar a pandemia. Revista Educação Básica em Foco, [S. l.], v. 1, n. 1, p. 1-8, 2020.

NEIRA, Marcos Garcia. Educação física cultural: inspiração e prática pedagógica. Jundiaí: Paco, 2019. DOI: $10.5585 /$ eccos.n48.12395.

OLIVEIRA, Luiz Fernandes De; CANDAU, Vera Maria Ferrão. Pedagogia decolonial e educação antirracista e intercultural no Brasil. Educação em Revista, [S. l.], v. 26, n. 1, p. 15-40, 2010. DOI: 10.1590/s010246982010000100002.

SALDAÑA, Johnny. The coding manual for qualitative researchers. London: Sage Publications, 2016. v. 53

SILVA, Juliana Pereira; URT, Sonia da Cunha. Músicas infantis e representações sociais: um descompasso social. Revista Teias, [S. l.], v. 17, n. 45, p. 243-259, 2016. DOI: 10.12957/teias.2016.24606.

SOPRANA, Paula. 70 milhões de brasileiros têm acesso precário à internet na pandemia do coronavírus. Folha de S. Paulo, São Paulo, 2020. Disponível em: https:/www1.folha.uol.com.br/mercado/2020/05/cerca-de70-milhoes-no-brasil-tem-acesso-precario-a-internet-na-pandemia.shtml. Acesso em: 8 set. 2020.

YIN, Robert K. Case Study Research: Design and Methods. London: Sage Publications, 2013. 


\section{Correspondência}

Raul Cabral França: É graduado em Relações Internacionais pela Universidade de São Paulo e mestre em Educação pela Universidade Estadual de Campinas. Atualmente realiza sua pesquisa de doutorado na mesma instituição. É membro do Grupo de Estudos e Pesquisas em Educação Continuada (GEPEC).

E-mail: raulfranca@gmail.com

Marina Basques Masella: É graduada em Pedagogia pela Universidade de São Paulo e especialista em Práticas Inclusivas na Educação pelo Instituto Singularidades. Atualmente é Professora da Escola Municipal de Educação Infantil Nelson Mandela, em São Paulo.

E-mail: marinabasques@hotmail.com

Ana Maria Falcão de Aragão: É Psicóloga. Professora titular do Departamento de Psicologia Educacional da Faculdade de Educação da Universidade Estadual de Campinas. Membro titular do Grupo de Estudos e Pesquisas em Educação Continuada (GEPEC) e membro convidado do Grupo de Estudos e Pesquisas em Educação Moral (GEPEM). Atua principalmente nos temas: formação de professores, reflexividade docente, processo de ensino e de aprendizagem, psicologia educacional, convivência ética e democrática na escola, gestão educacional e atuação do psicólogo escolar.

E-mail: anaragao@terra.com.br

Texto publicado em Currículo sem Fronteiras com autorização dos autores 